Original Research Paper

\title{
Determinants of Technical Efficiency of Sugarcane Production among Small Holder Farmers in Lao PDR
}

\author{
Poungchompu Supaporn \\ Department of Agricultural Economics, Faculty of Agriculture, KhonKaen University, KhonKaen, 40002, Thailand
}

Article history

Received: 27-08-2015

Revised: 01-09-2015

Accepted: 10-09-2015

Email: psuppap@kku.ac.th

\begin{abstract}
This study was to examine technical efficiency in sugarcane production in Savannakhet, Lao PDR. A stochastic frontier production function was applied with the data collected from 110 sample farmers in 2012. The results reveal that cultivated area $(p<0.01)$, hired labor $(p<0.10)$ and capital $(p<0.10)$ are the major significantly positive factors in the output of sugarcane. Mean of technical efficiency was found to be 0.7431 . In order to increase the efficiency of sugarcane farms improvements in farmers' education and extension service are the two most important variables which can be used by policy makers.
\end{abstract}

Keywords: Contract Farming, Sugarcane, Production, Technical Efficiency, Socio-Economics, Lao PDR

\section{Introduction}

Under the Ayeyawady-Chao Phraya-Mekong Economic Cooperation Strategy (ACMECS), a sugar factory in Thailand invested their capital in a sugarcane plantation as a new crop in Savannakhet province, Lao PDR in 2008. It was agreed that the Savannakhet authority would provide support in the forms of land and utilities for sugarcane production. Sugarcane production is classified as an industrial agricultural product characterized by large-scale plantations which employ advanced techniques and technologies. In addition, land is accessed through a concession. Sugarcane is a new crop which has become a main source of income and the second most dominant crop, (covering 12,390 ha) next to paddy rice in Savannakhet (MPI, 2010). This growing area is the largest sugarcane production area in the country. At present, the sugar factory has a 40-year concession to cultivate sugarcane on 10,000 hectares under a contract farming program entitled project $2+3$ of the Lao PDR government which called for the contribution of two production inputs, i.e., land and labor from the Lao farmers and a further three inputs, i.e., capital, technical skills and a purchasing contract, from the factory. The factory has the concession area of 7,362 ha and the contract farming area of 2,446 ha. Our preliminary study showed that the investment from the sugar factory in the form of contract farming has not only transferred modern technologies in sugarcane cultivation to the Lao nation, but also contributed economic benefits to the Lao farmers and communities, such as the increase of local people's income and the promotion of vacant land used for profitable activities, especially vacant land along the roads.

The contract farming of the sugar factory has established conditions in which they provide all production inputs including technologies to the farmers in terms of credits. All production inputs on credit are deducted after the farmers supply their sugarcane product to the company. The company would provide their technical staff to the farmers for consultation on the management of the sugarcane plantation and their purchasing transactions. The farmers are to be responsible for farm management only. However, under contract farming only $50 \%$ of farmers have achieved profitable returns from their sugarcane cultivation. The rest of the farmers could not gain productive returns. Moreover, yield decreased over time to less than 40 ton/ha, which was considered low compared to the average sugarcane production in Thailand of about 64 tones/ha. Lack of experience in sugarcane farm management and knowledge of sugarcane production, in addition to the more serious pest and disease outbreaks were considered the causing factors. Over the years farmers have also faced some difficulties related to sugarcane pests and diseases due to high humidity levels. Thus, quite a significant portion of the plantations were damaged by disease. Another problem faced is related to labor. Due to their subsistence lifestyle which is not conducive to the hard work required by sugarcane production management, farms found it difficult to fulfill quotas. These aforementioned physical and socioeconomic factors negatively influenced the technical efficiency of production. As a result, high yields were not fully achieved on sugarcane production even through 
a high yielding variety of crop and technologies are used. Thus, it can be stated that sugarcane production in Lao PDR is of low efficiency. Thus, there is a need to improve efficiency levels to raise productivity to achieve the maximum output and to minimize the cost of production. In order to attain the goal of improving efficiency of sugarcane production, identification and quantification of factors affecting the technical efficiency are needed. Emphasis of the study was on exploring the hypothesis that socio-economic factors are the main factors influencing sugarcane production.

\section{Methodology}

\section{Study Area and Sampling Procedure}

The study area was Savannakhet $\left(16^{\circ} 33^{\prime} 0^{\prime \prime}\right.$ north, $104^{\circ} 45^{\prime} 0^{\prime \prime}$ east). It lies in the southern part of the country bounded by Khammouan Province to the north, Quang Tri and Thua Thien-Hue provinces of Vietnam to the east, Salavan Province to the south and Nakhon Phanom and Mukdahan provinces of Thailand to the west. Savannakhet is the largest and most populous province of Laos, with a population of approximately 906,440 people consisting of 448,086 males and 458,354 females (LNTA, 2013). The province is comprised of 15 districts and 1,015 villages. The total area is approximately 21,774 square kilometers.

The data used were collected during August-October 2012 through a questionnaire distributed to smallholding farmers. Respondents were identified and selected through the multistage sampling technique. In the first stage, Xayaboury district was purposively selected due to its being the largest sugarcane production in the country. In the second stage, eleven out of twenty villages in this district were randomly chosen on the advice of Lao government officials including Kumnonsung, Dongpung, Ganghat, Laowpai, Yangkam, Pakkaya, Namaung, Woungtai, Laowdogmai, Krajuck and Nadang. In the final stage, ten farmers were randomly selected from each village that totaled 110 farmers.

\section{Analytical Techniques}

Efficiency is concerned with optimal values of production (Lovell, 1993). There are different types of efficiency; namely, productive efficiency is the optimal combination of inputs to produce maximum output with the minimum cost; economic efficiency is related to Pareto optimality that an input-output bundle is not in Pareto optimal, some are in inefficiency in the economy which can increase output or decrease input (Fare et al., 1985 and Daraio and Simar, 2007). Another is the technical efficiency is the effectiveness with an inputoutput that is technically efficiency (Koopmans, 1951). Essentially there are two main methodologies for measuring technical efficiency: Stochastic frontier (the econometric parametric) and Data envelopment analysis (non-parametric). The both techniques relies on a graphically explanation in two or three dimensions that are consistent with economic theory and Pareto optimality (Fried et al., 1993).

Following Aigner et al. (1977) (Meeusen and Broeck, 1977; Battese and Coelli, 1988), technical efficiency of sugarcane production was estimated using the stochastic production function. The original model was given in Equation 1:

$$
\mathrm{Y}_{\mathrm{i}}=\mathrm{f}\left(\mathrm{X}_{\mathrm{i}} ; \beta\right)+\varepsilon_{j}
$$

where, $\mathrm{Y}_{\mathrm{i}}$ is the output of the $i^{\text {th }}$ farm; $\mathrm{X}_{\mathrm{i}}$ is input for the $i^{\text {th }}$ farm and $\beta$ is a vector of parameters to be estimated. $\varepsilon_{j}$ represents an error term that is composed of two components as defined in Equation 2:

$\varepsilon_{j}=\mathrm{v}_{\mathrm{i}}-\mathrm{u}_{\mathrm{i}}$

where, $\mathrm{v}_{\mathrm{i}}$ is the two-sided normally distributed random error, $\mathrm{N}\left(0 ; \sigma_{v}{ }^{2}\right)$ that measures the stochastic effects outside the farmer' $s$ control. $u_{i}$ is a one-sided error term, $N(0$, $\sigma_{u}{ }^{2}$ ) that involves the technical inefficiency of farmer (Aigner et al., 1977). Moreover, Battese and Coelli (1995) expressed the inefficiency effects as an explicit function of a vector of farm-specific variables in Equation 3:

$u_{j}=\delta z_{j}$

where, for farm $j, z$ is a vector of observable explanatory variables and $\delta$ is a vector of unknown parameters which are assumed to be independently distributed, obtained by truncation of the normal distribution with mean zero and unknown variance, $\sigma^{2}$.

\section{Empirical Model}

A Cobb-Douglas Stochastic frontier production model was used in this study is given by Equation 4:

$$
\begin{aligned}
& \operatorname{LnY}_{1}=\beta_{0}+\beta_{1} \operatorname{Ln}\left(X_{1}\right)+\beta_{2} \operatorname{Ln}\left(X_{2}\right) \\
& +\beta_{3} \operatorname{Ln}\left(X_{3}\right)+\beta_{4} \operatorname{Ln}\left(X_{4}\right)+v_{i}-u_{i}
\end{aligned}
$$

where, $\mathrm{Y}$ is the yield of sugarcane (ton); $X_{1}, X_{2}, X_{3}$ and $X_{4}$ denote the cultivated area (ha), chemical fertilizer (bag), hired labour (in mandays) and capital (Baht) respectively. $\beta_{1}, \beta_{2}, \beta_{3}$ and $\beta_{4}$ are coefficients to be estimated that will have positive signs and $v_{i}-u_{i}$ are error terms.

The model for assessing technical inefficiency is given by Equation 5:

$u_{j}=\delta_{0}+\delta_{1} \mathrm{Z}_{1}+\delta_{2} \mathrm{Z}_{2}+\delta_{3} \mathrm{Z}_{3}$

where, $u_{j}$ is the inefficiency effects; $Z_{1}, Z_{2}$ and $Z_{3}$ is age of farmers (in years), years of schooling (in years), 
extension service (Dummy $0=$ No, $1=$ Yes) and the signs of coefficients for $\delta_{1}, \delta_{2}$ and $\delta_{3}$ are interpreted in a negative sign.

The variables commonly used in many previous studies to investigate the efficiency of farm were farm size, age of farmer, education level and extension services (Amara et al., 1999; Kalirajan and Shand, 1989; Seyoum et al., 1998). The estimates for all parameters in the Equation 1-4 are estimated by the method of maximum likelihood, using the computer program FRONTIER version 4.1 (Coelli, 1996).

\section{Results}

\section{Socio-Economic Characteristics of Sugarcane Production}

Farmers' ages varied between 27 and 79 years. The mean age was 48 years (Table 1). At this age, farmers had acquired experience in farming. The majority (73.1\%) farmers in the study area had elementary education as revealed by the mean year of schooling of 5.59 years indicating low levels of education. Approximately $62.72 \%$ of all farmers did not have training in sugarcane cultivation. In addition, the average sugarcane output per annum was 330.31 ton under the average farm size of 5.4 ha. Labor share in the production constituted a mean of 27.02 man days. Fertilizer was used extensively, with an average consumption of 32.91 bags $(1 \mathrm{bag}=50 \mathrm{~kg})$. The amount of capital was 90,490.12 Baht $(1$ Baht $=250$ Lao Kip) on average indicating that production was capital intensive (Table 1).

\section{Production Analysis}

All the estimated coefficients of the variables of the production function were positive (Table 2). The positive coefficients of cultivated area $\left(\mathrm{X}_{1}\right)$, chemical fertilizer $\left(X_{2}\right)$, hired labor $\left(X_{3}\right)$ and capital $\left(X_{4}\right)$ imply that as each of these variables increased, sugarcane output increased. Moreover, the cultivated area, hired labor and capital significantly affected the output of sugarcane at 1,10 and $10 \%$ level of significance respectively. There were trends of positive effects of the cultivated area, hired labor, capital inputs and of a positive effect of chemical fertilizer input on the output of sugarcane but it was not significant. The estimated coefficients for cultivated land, hired labor and capital were $0.961,0.032$ and 0.317 respectively. In short, a one percent increase in the land, hired labor and capital under sugarcane production would induce an increase of $96.1 \%$ for land, $3.2 \%$ for hired labor and $31.7 \%$ for capital in the output of sugarcane.

\section{Farm Levels of Technical Efficiency and Inefficiency}

The analysis of the data for the technical efficiency estimates was obtained through the Maximum Likelihood Estimation (MLE) of the Stochastic Frontier Function. The variance parameters of the stochastic frontier model are given in Table 2. Sigma squared $\left(\delta^{2}\right)$ and gamma $(\gamma)$ were significantly. The parameter sigma squared was 0.043 and significantly $(\mathrm{p}<0.01)$ meaning that it was a good fit and had correctness of the distributional form while the value of gamma equal to 0.959 was statistically significant $(p<0.01)$. This value indicated that about $95.9 \%$ of the variation in the production of sugarcane implying that the random component of the inefficiency effects has a significant contribution in the production analysis (Coelli and Battese, 1996). The coefficient of age variable was significantly $(p<0.10)$ negative in relation to the technical inefficiency suggesting that the elderly led to technical efficiency among the farmers. Similarly, years of schooling showed a significant $(p<0.10)$ negative coefficient meaning that an increase in the number of school years decreased technical inefficiency. Moreover, the variable related to extension services received showed a significant $(\mathrm{p}<0.01)$ negative coefficient indicating that increases in this variable would reduce the inefficiency of the farmer.

Table 1. Definition of variables and descriptive statistics

\begin{tabular}{|c|c|c|c|}
\hline Variables & Description & Mean & SD \\
\hline \multicolumn{4}{|c|}{ Production function } \\
\hline Y & Yield of sugarcane (ton) & 330.31 & 266.85 \\
\hline $\mathrm{X}_{1}$ & Cultivated Area (ha) & 5.40 & 4.45 \\
\hline $\mathrm{X}_{2}$ & Chemical fertilizer (bag, $1 \mathrm{bag}=50 \mathrm{~kg}$ ) & 32.91 & 28.73 \\
\hline$X_{3}$ & Hired labour (in man days) & 27.02 & 19.00 \\
\hline $\mathrm{X}_{4}$ & Capital (baht) & $90,490.12$ & $76,006.70$ \\
\hline \multicolumn{4}{|c|}{ Inefficiency model } \\
\hline $\mathrm{Z}_{1}$ & Age of farmers (in years) & 48.00 & 11.36 \\
\hline $\mathrm{Z}_{2}$ & Schooling year (in years) & 5.59 & 3.79 \\
\hline \multirow[t]{3}{*}{$\mathrm{Z}_{3}$} & Extension services & & \\
\hline & 0 No & 62.72 & \\
\hline & 1 Yes & 37.28 & \\
\hline
\end{tabular}


Table 2. Maximum likelihood estimation of the production frontier for sugarcane production

\begin{tabular}{|c|c|c|c|}
\hline Variables & Parameter & Coefficient & t-ratio \\
\hline \multicolumn{4}{|l|}{ Production function } \\
\hline Constant & $\mathrm{B}_{0}$ & 0.311 & $16.013^{* * * *}$ \\
\hline Cultivated area $\left(\mathrm{X}_{1}\right)$ & $\mathrm{B}_{1}$ & 0.961 & $18.795^{* * *}$ \\
\hline Chemical fertilizer $\left(\mathrm{X}_{2}\right)$ & $\mathrm{B}_{3}$ & 0.015 & $0.371^{\mathrm{NS}}$ \\
\hline Hired labor $\left(\mathrm{X}_{3}\right)$ & $\mathrm{B}_{4}$ & 0.032 & $1.415^{*}$ \\
\hline Capital $\left(\mathrm{X}_{4}\right)$ & $\mathrm{B}_{5}$ & 0.317 & $1.693^{*}$ \\
\hline \multicolumn{4}{|l|}{ Inefficiency model } \\
\hline Constant & $\delta_{0}$ & 0.357 & $6.665^{* * *}$ \\
\hline Age of farmer $\left(Z_{1}\right)$ & $\delta_{1}$ & -0.189 & $-1.386^{*}$ \\
\hline Schooling year $\left(\mathrm{Z}_{2}\right)$ & $\delta_{2}$ & -0.062 & $-1.593^{*}$ \\
\hline Extension services $\left(\mathrm{Z}_{3}\right)$ & $\Delta_{4}$ & -0.209 & $-3.278^{* * *}$ \\
\hline \multicolumn{4}{|l|}{ Variance parameter } \\
\hline Likelihood ratio & & 45.740 & \\
\hline Sigma-square $\left(\delta^{2}\right)$ & & 0.043 & $3.411^{* * *}$ \\
\hline Gamma (r) & & 0.959 & $17.599^{* * *}$ \\
\hline TE mean & & 74.310 & \\
\hline
\end{tabular}

$* * *=0.01, * *=0.05, *=0.10, \mathrm{NS}=$ Not Significant

Table 3. Frequency distribution of technical efficiency among sugarcane farmer

\begin{tabular}{lcr}
\hline Range of TE & Frequency & Percentage \\
\hline Less than 0.49 & 6 & 5.46 \\
$0.50-0.59$ & 14 & 12.72 \\
$0.60-0.69$ & 21 & 19.09 \\
$0.70-0.79$ & 27 & 24.55 \\
$0.80-0.89$ & 25 & 22.73 \\
More than 0.90 & 17 & 15.45 \\
\hline
\end{tabular}

The predicted Technical Efficiency (TE) among the farmers ranged from 0.48 to 0.97 with the mean TE of 0.7431 (Table 2) indicating a 74.31\% mean TE of sugarcane. Also, approximately $37.27 \%$ of sugarcane farmers attained less than 0.69 efficiency level. Moreover, the distribution in the technical efficiency of the farmers reveals that approximately $51.81 \%$ of the sugarcane farmers had TE index below the mean TE while the remaining farmers were those with TE above the TE mean. Only $15.45 \%$ of sugarcane farmers had TE over 0.90 (Table 3 ).

\section{Discussion}

The findings of the study revealed that all inputs contributed positively to the output of sugarcane production. However, some of these inputs, i.e., cultivated area, hired labors and capital was not used to their optimal levels for sugarcane production. Therefore, farmers would have obtained higher productivity by increasing the cultivated area and hired labor in sugarcane production. More importantly, capital in sugarcane production system was capital intensive. This was brought about by the use of machinery in various steps of sugarcane production including land clearing, land preparation and planting. Under contract between the Thai contractor company and the Lao farmers, these steps were done by the contractor according to their specifications, for example depth and width of ploughing and planting. High demand for land clearance during the planting season meant that the contractor could not provide services to all sugarcane households on time, resulting in insufficient ploughing and late planting for some households with the ultimate consequence being low yields. In addition, this operation led to increases in production costs related to machinery cost which was incurred by the non-transparency of the production process. The various production steps performed by the contractor company were coordinated through a Thai sub-contractor and a representative from each village. This could have led to collusion of the two parties in their various joint operations.

Therefore, the contracted farmers were at risk of increasing production costs and unsuccessful sugarcane growing. These conditions presented above showed that the farmers had a low technical efficiency. This was substantiated by the inefficiency factor with the mean TE of $74.31 \%$ which was upper than those of sugarcane farms in Phillippines (72.98\%) (Padilla-Fernandez and Peter, 2009) but lower than India (79\%) (Rangalal, 2011) and Pakistan (75\%) (Heman et al., 2011). The inefficiency resulted from the following factors, i.e., farmers' age, their educational levels and of extension services sugarcane cultivation. It is conceivable that older heads of households would have more experience in crop production that could lead to more efficient production. This finding was supported by those of Amara et al. (1999) and Coelli and Battese (1996). The positive contribution of educational level to technical efficiency was in agreement with the results obtained by (Romain and Lambert, 1995; Seyoum et al., 1998; Weir, 1999; Weir and Knight, 2000; Coelli and Battese, 1996). This result showed that farmers who have spent many years in formal education tend to be more efficient in sugarcane production due to their enhanced ability to 
acquire technical knowledge. The majority of sugarcane farmers had a relatively low level of educational attainment and engaged in independent, subsistence agricultural production. The low educational level as well as a lack of experience in industrial production remained a constraint for investment in the area, especially with regard to implementing contract farming using modern techniques and technologies. Thus, there is a need for a policy to promote formal education to improve the educational qualifications of farmers which will enhance efficiency in sugarcane production and help them to be conscious about allocating their production inputs effectively. In addition, the increased efficiency of the farmers in sugarcane production related to extension services was consistent with the results of (Kalirajan and Shand, 1989; Seyoum et al., 1998; Amaza et al., 2006; O'Neill et al., 1949).

However, in Laos PDR the extension services have poor extension services. Their methods only involved organizing farming support groups and the distribution of flyers on general agricultural information. In addition, training methodologies were poor as indicated by impromptu training of the farmers without proper preparation steps. They also had limited resources which did not enable them to follow through with the whole extension process from initiation to implementation and to follow up. With regards to the extension staff, they were limited in technical knowledge and experiences. As a result, the staff does not identify with the project, nor possess personal objectives, but simply operates in accordance with direction and policy. This is a severe issue facing the development of Lao's extension system. Thus, it is recommended that the extension staff improve their skills to be able to better support the farmers and provide information services to farmers through the reform of agricultural and forestry colleges (Douangtavilay, 2003). This should lead to improved extension services to farmers which will distribute to their acquisition of new knowledge, skills and practices on using improved technology as well as being more innovative.

\section{Conclusion}

In order to improve profitability, it is recommended that farmers make input use more efficient by reducing capital and fertilizer application. The priority implication of the foregoing analyses is that farmers' education and extension services are the two most important policy variables which can be used by policy makers to improve the current level of technical efficiency for farmers in Laos.

\section{Acknowledgement}

The author thanks to National Economic Research Institute (NERI) in Lao PDR for research survey and informative data and Thailand Research Fund (RDG5510009) for finance support.

\section{Funding Information}

This article was funded from Thailand Research Fund (TRF) (+66 82002278$)$.

\section{Author's Contributions}

Poungchompu Supaporn: Managed farm survey and made interpretation of data. Also, she critically reviewed the manuscript.

\section{Ethics}

The author has approved this manuscript and no ethical issue appeared.

\section{References}

Aigner, D., C.K. Lovell and P. Schmidt, 1977. Formulation and estimation of stochastic frontier production function models. J. Econometr., 6: 21-37. DOI: 10.1016/0304-4076(77)90052-5

Amara, N., N. Traore, R. Landry and R. Romain, 1999. Technical efficiency and farmers' attitudes toward technical innovation: The case of the potato farmers in Quebec. Canadian J. Agric. Econ., 47: 31-43. DOI: 10.1111/j.1744-7976.1999.tb00214.x

Amaza, P.S., Y. Bila and A.C. Iheanacho, 2006. Identification of factors that influence technical efficiency of food crop production in West Africa: Empirical evidence from Borno state, Nigeria. J. Agric. Rural Develop. Tropics Subtrop., 107: 139-147.

Battese, G.E. and T.J. Coelli, 1988. Prediction of firmlevel technical efficiencies with a generalized frontier production function and panel data. J. Econometr., 38: 387-399. DOI: 10.1016/0304-4076(88)90053-X

Battese, G.E. and T.J. Coelli, 1995. A model for technical inefficiency effects in a stochastic frontier production function for panel data. Empirical Econom., 20: 325-332. DOI: 10.1007/BF01205442

Coelli, T.J. and G.E. Batesse, 1996. Identification of factors which influence the technical inefficiency of Indian farmers. Am. J. Agric. Econom., 40: 103-128. DOI: $10.1111 /$ j.1467-8489.1996.tb00558.x

Coelli, T.J., 1996. A guide to frontier 4.1: A computer programmer for stochastic frontier production and cost function estimation: 1-33. Department of Econometrics, University of New England.

Daraio, C. and L.Simar, 2007. Advanced robust and nonparametric methods in efficiency analysis: methodology and applications., Springer Science, Inc., New York, ISBN-10: 9780387351551, pp: 248. 
Douangtavilay, S., 2003. Enhancement of extension systems in agriculture. Asian Productivity Organization, Japan.

Fare, R., S. Grosskopf and C.A.K. Lovell, 1985. The Measurement of Efficiency of Production. 1st Edn., Springer Science and Business Media, Boston, ISBN-10: 089838155X, pp: 216.

Fried, H., C. Lovell and S. Schmidt, 1993. The Measurement of Productive Efficiency: Techniques and Applications. 1st Edn., Oxford University Press, USA, New York, ISBN-10: 0195361105, pp: 440.

Heman, D.L., A. Nazir and A.M. Khushk, 2011. Technical, allocative and economic efficiencies in sugarcane production in Pakistan: A non-parametric approach. Bus. Rev., 6: 131-143.

Kalirajan, K.P. and R.T. Shand, 1989. A generalized measure of technical efficiency. Applied Econom., 21: 25-34. DOI: 10.1080/772284229

Koopmans, T.C., 1951. An Analysis of production as an efficient combination of Activities. In: Activity analysis of production and allocation, Koopmans, T.C. (Ed.), Wiley, New York, pp: 404.

LNTA, 2013. Savannakhet Province, Central Laos. The Lao National Tourism Administration.

Lovell, C.A.K., 1993. Production frontiers and productive efficiency. In: The measurement of productive efficiency: Techniques and applications. Fried, H., C. Lovell and S. Schmidt (Eds.), Oxford University Press, USA, New York, ISBN-10: 0195361105, pp: 440.

Meeusen, W. and J. van den Broeck, 1977. Efficiency estimation from Cobb-Douglas production functions with composed error. Int. Economic Rev., 18: 435-444. DOI: 10.2307/2525757
MPI, 2010. Contract farming in Lao PDR. Ministry of Planning and Investment, Investment Promotion Department.

O'Neill, S., A. Leavy and A. Matthews, 1949. Measuring productivity change and efficiency on Irish farms. End Project Report., 4498: 1-13.

Padilla-Fernandez, M.D. and L.N. Peter, 2009. Technical efficiency in the production of sugar cane in central Negros area, Philippines: An application of data envelopment analysis. J. Int. Soc. Se. Asian. Agric. Sci., 15: 77-90.

Rangalal, M., 2011. Farmers' education and profit efficiency in sugarcane production: A stochastic frontier profit function approach. IUP J. Agric. Econom., 8: 18-35.

Romain, R. and R. Lambert, 1995. Efficacite technique et couts de production dans les secteurs laitiers du Quebec et de 1=ontario. Canadian J. Agric. Economic., 43: 37-55. DOI: $10.1111 / \mathrm{j} .1744-7976.1995 . t b 00106 . x$

Seyoum, E.T., G.E. Battese and E.M. Fleming, 1998. Technical efficiency and productivity of maize producers in eastern Ethiopia: A study of farmers within and outside the Sasakawa-Global 2000 project. Agric. Economic., 19: 341-348. DOI: $10.1016 / \mathrm{S} 0169-5150(98) 00037-1$

Weir, S., 1999. The Effects of education on farmer productivity in rural Ethiopia. 1st Edn., University of Oxford, UK, pp: 50.

Weir, S. and J. Knight, 2000. Education externalities in rural Ethiopia: Evidence from average and stochastic frontier production functions. Centre for the Study of African Economies, University of Oxford, UK. 